1. FCPS General Surgery Senior Registrar Department of Surgical Unit 1 Holy Family Hospital Rawalpindi Medical University.

2. FCPS General Surgery Assistant Professor Department of Surgery Surgical Unit Holy Family Hospital Rawalpindi.

3. Third Year MBBS

Medical Student

$\mathrm{CMH}$, Lahore.

4. Post Graduate Trainee

Department of Surgical Unit 1 Holy Family Hospital Rawalpindi.

Rawalpindi Medical University

5. Post Graduate Trainee

Department of Surgical Unit 1

Holy Family Hospital Rawalpindi Rawalpindi Medical University.

6. MBBS, FCPS, FRCS, FACS, FICS DIP. M.ED

Professor of Surgery

Department of Surgical Unit Holy Family Hospital

Rawalpindi Medical University

Correspondence Address:

Dr. Ramlah Ghazanfor

Department of Surgical Unit 1

Holy Family Hospital

Rawalpindi Medical University.

ramla.an99@gmail.com

Article received on:

06/09/2018

Accepted for publication:

$15 / 12 / 2018$

Received after proof reading:

$31 / 07 / 2019$

\section{COMPARATIVE STUDY OF EFFECTIVENESS OF VITAMIN E AND EVENING PRIMROSE OIL FOR PAIN RELIEF IN MODERATE CYCLICAL MASTALGIA.}

Ramlah Ghazanfor ${ }^{1}$, Usman Qureshi ${ }^{2}$, Rafay Ghazanfer Adil ${ }^{3}$, Sara Malik ${ }^{4}$, Maham Tariq ${ }^{5}$, Jahangir Sarwar Khan ${ }^{6}$

ABSTRACT... In breast clinics worldwide, cyclical mastalgia is the commonest presenting complaint among patients of reproductive age. Non-pharmacological options are preferred mode of treatment due to their better side effect profile. This study compares the effectiveness of two such non-pharmacological options i.e. Vitamin E and Evening Primrose Oil. Study Design: Randomized controlled single blinded trial. Setting: Surgical Unit 1 Holy Family Hospital, Rawalpindi. Period: Six months from July to Dec 2017. Materials and Methods: Observing all scientific and ethical protocols. All non-pregnant and non-lactating females of reproductive age were included in study. Two groups A and B, of 190 patients each, were made. Group A received Vitamin $E$ capsules 400 mg once daily whereas group B received evening primrose oil $500 \mathrm{mg}$ capsules twice daily. After six months, mean reduction in pain scores in both groups was calculated using a t-test ( $p$-value $<0.05$ was considered significant). Results: Total number of 380 female patients (190 in each group) were enrolled in study for a period of 6 months. Mean age was $30.00+16.54$ years. Mean score at presentation was $5.69+0.08$ in vitamin $E$ group and $5.66+0.8$ in EPO group. After 6 months, score was $3.70+1.5$ in vitamin E group and $4.78+1.47$ in EPO group, which was statistically significant ( $p$ value $<0.05)$. Conclusion: Vitamin $E$, when taken for 6 months, is more effective than evening primrose oil in reducing pain in moderate cyclical mastalgia.

Key words: $\quad$ Cyclical Mastalgia, Evening Primrose Oil, Gamma linolenic acid (GLA), NSAIDs, Vitamin E

Article Citation: Ghazanfor R, Qureshi U, Adil RG, Malik S, Tariq M, Khan JS. Comparative study of effectiveness of vitamin $E$ and evening primrose oil for pain relief in moderate cyclical mastalgia. Professional Med J 2019; 26(8):1328-1332. DOI: 10.29309/TPMJ/2019.26.08.3878

\section{INTRODUCTION}

Mastalgia is one of the commonest presenting complains in breast clinics with prevalence rate of $30 \% .^{1}$ It's usually classified in cyclical mastalgia (75\%) and non-cyclical mastalgia $25 \% .^{2}$

Cyclical mastalgia is defined as cyclical swelling, discomfort and pain in one or both breasts occurring mostly one week before menstruation and settling with its onset. Although no single underlying mechanism has been mentioned in literature; various hypothesis regarding its pathophysiology have been put forth; including increased serum prolactin levels, hypersensitivity to estrogen, decreased serum progesterone, deficiency of antioxidants or gamma linoleic acid levels in body. Although not associated with an increase in risk of malignancy, cyclical mastalgia is often severe enough to effect marital relationships in $41 \%^{3}$ and sleep pattern in $35 \%$ of its victims, Ten percent of patients suffer for nearly half of their lives. ${ }^{4}$

Current treatment options available for this disorder range from psychological assurance ${ }^{5}$, supportive undergarments ${ }^{6,7}$, lifestyle and dietary modifications $^{8}$, use of supplements like Vitamin E, Evening Primrose Oil, fish oil, flaxseed oil ${ }^{9}$ centchromans etc. Pharmaceutical options include topical and oral NSAIDs, danazol ${ }^{10}$, tamoxifen $^{11}$, bromocriptine ${ }^{12}$ and luteinizing hormone releasing antagonists. Since use of any of the above mentioned pharmaceutical preparations is not free from side-effects ${ }^{9}$, current trend is to prescribe supplements as first line treatment for mild to moderate cyclical 
mastalgia. ${ }^{13}$

One of these supplements, Vitamin E or alpha tocopherol, acts as an antioxidant agent having stabilizing effect on breast cells' epithelium protecting them from injurious free radicals that are produced in sundry metabolic processes of body. ${ }^{14}$ Due to its low side effect profile, Vitamin $E$ has long been promoted as a safe treatment option especially in fertile women suffering from cyclical mastalgia. ${ }^{15}$ Evening primrose oil (Oenothera biennis) is plant oil rich in omega 6 fatty acids, especially gamma linolenic acid (GLA). Patients of cyclical mastalgia are often postulated to have lower ratio of GLA to unsaturated fatty acids causing breast tissue epithelium to become hypersensitive to circulatory hormones levels. Another hypothesis suggests significant role of GLA at genetic levels in lipoxygenase and cyclooxygenase pathways producing antiinflammatory eicosanoids.

Over the time, both supplements have made their mark as acceptable options in treating cyclical mastalgia. However, the supremacy of one over other is disputed. Due to lack of evidence-based guidelines, most of the surgeons lean on their intuition or personal preference in choosing one drug over other. The rationale of current study is to generate local data in this aspect so that recommendations can be given for better patient management.

\section{Study Design}

After approval from hospital's ethical committee, a randomized controlled single blinded trial was conducted at Surgical Unit-1 of Holy Family Hospital Rawalpindi, for a period of six months i.e. June to Dec 2016 (permitted by the Research and Ethical Committee, Rawalpindi Medical College and Allied Hospitals, RMC/PR_01/Jan 2015). A sample size of 380 patients, 190 in each group, was calculated using WHO calculator. Moderate cyclical mastalgia was defined as pain and heaviness in breasts beginning before menstruation and relieving at end of it with pain score between 4-7 on visual analogue scale. All females of reproductive age (15-45 years) were included. Those who were pregnant, lactating or had a history of breast trauma were excluded. All patients were clearly informed about the purpose, procedure and blinding process of the study. After obtaining written informed consent, group allocation was done by simple lottery method. A total of 380 chits with half labelled as $A$ and remaining half labelled as $B$ were put in a box. Every patient drew a chit and was allocated to the corresponding group. Patient remained unaware of their group type throughout the study. Group A received Vitamin E capsules $400 \mathrm{mg}$ once daily whereas group $B$ received evening primrose oil $500 \mathrm{mg}$ capsules twice daily. Visual analogue scale was used to calculate pain scores at beginning and and end of study period. Data were entered and analyzed using the Statistical Package for Social Sciences (SPSS), version 23.0 (IBM Corp., Armonk, NY).

For the quantitative variables of the study i.e. age, duration of disease and visual analogue scores, means along with standard deviations were calculated.

Effect modifiers like age and duration of disease were controlled by stratification. Post stratification independent sample t-test was applied. A p-value $<0.05$ was considered statistically significant.

\section{RESULTS}

Total 380 patients were enrolled in each group. Study was conducted for a period of 6 months. Mean age of patients was calculated to be $29.35 \pm 6.76$ years. Those enrolled in Vitamin $E$ group had mean age of $31.013 \pm 6.83$ years and those in evening primrose oil had $27.70 \pm 6.36$ years. All details regarding age are given in Table-I.

Pretreatment and post treatment mean pain scores were calculated in both groups. Difference in pain scores after treatment for six months were also calculated. There was significant difference of pain scores between two groups. Difference was found to be higher in vitamin $E$ group than evening primrose oil group. Details are given in Table-II.

The duration of symptoms in both groups was 
calculated. In vitamin $\mathrm{E}$ group mean duration of symptoms was $4.85+2.04$ months while in evening primrose oil group mean duration was 4.82 2.37 months. All details are given in Table-III.

Stratification for age and duration of symptoms were done and are summarized in Table-IV and V respectively.

\begin{tabular}{|c|c|c|c|c|}
\hline Age Group & \multicolumn{2}{|c|}{ Vitamin E Group } & \multicolumn{2}{|c|}{$\begin{array}{c}\text { Evening Primrose } \\
\text { Oil Group }\end{array}$} \\
\hline 15-30 Years & \multicolumn{2}{|l|}{93} & \multicolumn{2}{|c|}{140} \\
\hline 31-45 Years & \multicolumn{2}{|l|}{97} & \multicolumn{2}{|r|}{50} \\
\hline Mean \pm SD & \multicolumn{2}{|c|}{$31.01 \pm 6.83$ years } & \multicolumn{2}{|c|}{$27.70 \pm 6.36$ years } \\
\hline \multicolumn{5}{|c|}{ Table-I. Distribution of patients according to age } \\
\hline Groups & $\begin{array}{l}\text { Pain Scores } \\
\text { Before } \\
\text { Treatment }\end{array}$ & $\begin{array}{r}\text { Pain } 5 \\
\text { Af } \\
\text { Trea }\end{array}$ & $\begin{array}{l}\text { cores } \\
\text { mer }\end{array}$ & $\begin{array}{l}\text { Difference } \\
\text { in Pain } \\
\text { Scores }\end{array}$ \\
\hline $\begin{array}{l}\text { Vitamin E } \\
\text { Group }\end{array}$ & $5.76 \pm 9.65$ & 3.74 & \pm 1.6 & $2.05 \pm 1.89$ \\
\hline $\begin{array}{l}\text { Evening } \\
\text { Primrose } \\
\text { Oil Group }\end{array}$ & $5.60 \pm 0.82$ & 4.86 & \pm 1.44 & $0.76 \pm 1.5$ \\
\hline P-Value & 0.077 & & 00 & 0.00 \\
\hline
\end{tabular}

Table-II. Pre-treatment and post treatment mean pain scores in both groups

\begin{tabular}{|l|c|c|}
\hline $\begin{array}{c}\text { Duration of } \\
\text { Symptoms }\end{array}$ & Vitamin E Group & $\begin{array}{c}\text { Evening Primrose } \\
\text { Oil Group }\end{array}$ \\
\hline$\leq 6$ Months & 150 & 147 \\
\hline$>6$ Months & 40 & 43 \\
\hline Mean \pm SD & $\begin{array}{c}4.85 \pm 2.04 \\
\text { months }\end{array}$ & $4.82 \pm 2.37$ months \\
\hline
\end{tabular}

Table-III. Distribution of patients according to duration of symptoms

\begin{tabular}{|c|c|c|c|c|}
\hline \multirow{2}{*}{$\begin{array}{l}\text { Age } \\
\text { Group }\end{array}$} & \multirow{2}{*}{ Drugs } & \multicolumn{2}{|c|}{$\begin{array}{c}\text { Changes in Pain } \\
\text { Score }\end{array}$} & \multirow{2}{*}{ P-Value } \\
\hline & & $\begin{array}{c}\text { Number } \\
\text { (n) }\end{array}$ & Mean $\pm S D$ & \\
\hline & $\begin{array}{l}\text { Vitamin E } \\
\text { Group }\end{array}$ & 93 & $2.12 \pm 1.84$ & \multirow[b]{2}{*}{$<0.001$} \\
\hline $\begin{array}{l}15-30 \\
\text { Years }\end{array}$ & $\begin{array}{l}\text { Evening } \\
\text { Primrose } \\
\text { Oil Group }\end{array}$ & 140 & $0.721 \pm 1.55$ & \\
\hline \multirow[b]{2}{*}{$\begin{array}{l}31-45 \\
\text { Years }\end{array}$} & $\begin{array}{l}\text { Vitamin E } \\
\text { Group }\end{array}$ & 97 & $1.97 \pm 1.94$ & \multirow[b]{2}{*}{$\begin{array}{c}< \\
0.0001\end{array}$} \\
\hline & $\begin{array}{l}\text { Evening } \\
\text { Primrose } \\
\text { Oil Group }\end{array}$ & 50 & $0.78 \pm 1.41$ & \\
\hline
\end{tabular}

Table-IV. Stratification of mean pain score with respect to age groups

\begin{tabular}{|c|c|c|c|c|}
\hline \multirow{2}{*}{$\begin{array}{l}\text { Duration of } \\
\text { Symptoms }\end{array}$} & \multirow{2}{*}{ Drugs } & \multicolumn{2}{|c|}{ Changes in Pain Score } & \multirow{2}{*}{ P-Value } \\
\hline & & $\begin{array}{c}\text { Number } \\
\text { (n) }\end{array}$ & Mean \pm SD & \\
\hline \multirow[b]{2}{*}{$\begin{array}{l}\leq 6 \\
\text { Months }\end{array}$} & $\begin{array}{l}\text { Vitamin } \\
\text { E Group }\end{array}$ & 150 & $2.07 \pm 1.93$ & \multirow[b]{2}{*}{$\begin{array}{c}< \\
0.0001\end{array}$} \\
\hline & $\begin{array}{l}\text { Evening } \\
\text { Primrose } \\
\text { Oil } \\
\text { Group }\end{array}$ & 147 & $0.836 \pm 1.50$ & \\
\hline \multirow[b]{2}{*}{$\begin{array}{l}>6 \\
\text { Months }\end{array}$} & $\begin{array}{l}\text { Vitamin } \\
\text { E Group }\end{array}$ & 40 & $1.89 \pm 1.74$ & \multirow[b]{2}{*}{$\begin{array}{c}< \\
0.0001\end{array}$} \\
\hline & $\begin{array}{l}\text { Evening } \\
\text { Primrose } \\
\text { Oil } \\
\text { Group }\end{array}$ & 43 & $1.07 \pm 1.77$ & \\
\hline
\end{tabular}

Table-V. Stratification of mean pain score with respect to duration of symptoms

\section{DISCUSSION}

Cyclical mastalgia effects $30 \%$ patients worldwide, making it one of the commonest ailments in women during child bearing period. Side effect profile of drugs like tamoxifen, danazol, bromocriptine etc. preclude their use for all except the most recalcitrant cases only. This makes use of natural supplements an attractive treatment option. Several studies show Vitamin $E$ and EPO to be very useful in this regard. ${ }^{15}$ Both are a part of guidelines given by multiple centers, worldwide. However little work has been done in comparing their efficacy against each other. This study showed cyclical mastalgia to be predominantly a problem of young women less than 30 years of age $(61.05 \%)$. Most of the patients had been suffering for quite some time $(4.83 \pm 2.205$ months) before presenting to breast clinic. Patients having pain scores between 4 to 7 were included in the study. Those with score 8 or more were considered to be suffering from severe mastalgia. They received additional drugs like oral and topical NSAIDs and tamoxifen etc. and were not included in the study. Six months later, a change in pain scores in both groups was noted (Vitamin $E=2.05 \pm 1.89$, EPO $=0.76 \pm 1.5$ ). This was significant only for Vitamin $E$ receiving group ( $p$ value $<0.05$ ).

This was interesting as several studies in past have 
drawn conflicting conclusions. In 2010, Pruthi et al, in a pilot study, compared effects of both supplements when used alone or in combination for treatment of cyclical mastalgia. It was a pilot study with small sample size and high dropout rate. No drug was found to be superior, but a general trend of benefit was noted in all treatment arms. ${ }^{15}$ In 2011, Alvandipour et al, from Iran, also showed that both supplements were equally effective. ${ }^{16}$ However, Fathizadeh et al, endorsed that although both drugs reduced pain, EPO was in fact better than Vitamin $E$ when given in daily doses of 3 gram for several months ( $p$ value $p$ $<0.001) .{ }^{17}$ This result is in contradiction to our findings and is may be due to smaller dosage of EPO (1 gm per oral daily) used in our study.

Stratification of the data was done for both age and duration of symptoms. Two age groups of 15-30 years and 31-45 years were made. In Vitamin $E$ group, younger patients showed better improvement $(2.12 \pm 1.84)$ than older ones $(1.97 \pm 1.94)$. EPO group also showed similar findings but there the difference in change in score was not very great. This special effectiveness of Vitamin $E$ for ages less than 30 is important because majority sufferers also belonged to a younger group (61.05\%); thus, making it a choice medication for almost $2 / 3^{\text {rd }}$ of the patient population.

Stratification was also done for duration of symptoms, which revealed that those presenting early i.e. within 6 months of symptom had greater changes in mean pain sores than those presenting late.

Compliance was an issue found during the study. Most patients found it cumbersome to adhere to regimens lasting six months. Moreover, relief with both supplements was slow in onset. This caused few patients $(n=21)$ to opt for other treatment options e.g. NSAIDs, tamoxifen, bromocriptine. These offered swifter relief albeit at cost of side effects. Such patients were considered drop outs and not included in study.

\section{CONCLUSION}

Vitamin $\mathrm{E}$ when compared to Evening Primrose
Oil is more effective in reducing pain in moderate cyclical mastalgia and can be prescribed with confidence in these patients.

Copyright $(15$ Dec, 2018.

\section{REFERENCES}

1. Butt $S$, Farooqi MM, Ibnerasa S, Lodhi Y. Frequency of different female breast lesions in pathology department of Lahore Medical \& Dental College. Pak J Med Health Sci. 2014 Jan 1; 8:28-30.

2. Kanat $B H$, Atmaca $M$, Girgin $M$, Ilhan $Y S$, Bozdağ A, Özkan Z, et al. Effects of mastalgia in young women on quality of life, depression, and anxiety levels. Indian J Surg. 2016 Apr; 78(2):96-9.

3. Parsay S, Olfati $F$, Nahidi S. Therapeutic effects of vitamin E on cyclic mastalgia. Breast J. 2009 Oct; 15(5):510-4.

4. Shamsi U, Khan S, Usman S, Soomro S, Azam I. A multicenter matched case control study of breast cancer risk factors among women in Karachi, Pakistan. Asian Pac J Cancer Prev APJCP. 2013; 14(1):183-8.

5. Kataria K, Dhar A, Srivastava A, Kumar S, Goyal A. A systematic review of current understanding and management of mastalgia. Indian J Surg. 2014 Jun; 76(3):217-22.

6. Barros ACSD, Mottola J, Ruiz CA, Borges MN, Pinotti JA. Reassurance in the treatment of mastalgia. Breast $\mathrm{J}$. 1999 May; 5(3):162-5.

7. Hadi MSAA. Sports brassiere: Is It a solution for mastalgia? Breast J. 2000 Nov; 6(6):407-9.

8. Dennehy CE. The use of herbs and dietary supplements in gynecology: An evidence-based review. J Midwifery Women's Health. 2006 Nov 12; $51(6): 402-9$.

9. Li C-P, Lee F-Y, Hwang S-J, Chang F-Y, Lin H-C, Kuo BI-T, et al. Treatment of mastalgia with tamoxifen in male patients with liver cirrhosis: A randomized crossover study. Am J Gastroenterol. 2000 Apr 1; 95(4):1051-5.

10. Mansel RE, Harrison BJ, Melhuish J, Sheridan W, Pye $\mathrm{JK}$, Pritchard G, et al. A randomized trial of dietary intervention with essential fatty acids in patients with categorized cysts. Ann N Y Acad Sci. 1990 May 1; 586(1):288-94.

11. Messinis IE, Lolis $\mathrm{D}$. Treatment of premenstrual mastalgia with tamoxifen. Acta Obstet Gynecol Scand. 1988; 67(4):307-9. 
12. Kilicdag EB, Tarim E, Bagis T, Erkanli S, Aslan E, Ozsahin $\mathrm{K}$, et al. Fructus agni casti and bromocriptine for treatment of hyperprolactinemia and mastalgia. Int $\mathrm{J}$ Gynaecol Obstet Off Organ Int Fed Gynaecol Obstet. 2004 Jun; 85(3):292-3.

13. Holland PA, Gateley CA. Drug therapy of mastalgia. What are the options? Drugs. 1994 Nov; 48(5):709-16.

14. Ernster VL, Goodson WH, Hunt TK, Petrakis NL, Sickles EA, Miike R. Vitamin E and benign breast "disease": a double-blind, randomized clinical trial. Surgery. 1985 Apr; 97(4):490-4.
15. Pruthi S, Wahner-Roedler DL, Torkelson CJ, Cha SS, Thicke LS, Hazelton $\mathrm{JH}$, et al. Vitamin E and evening primrose oil for management of cyclical mastalgia: A randomized pilot study. Altern Med Rev J Clin Ther. 2010 Apr; 15(1):59-67.

16. $M A, P T, R A N, H K$. Comparison between effect of evening primrose oil and vitamin $E$ in treatment of cyclic mastalgia. 2011 Jan 1; 13(259):7-11.

17. Fathizadeh N, Takfallah L, Ehsanpour S, Namnabati M, Askari S. Effects of evening primrose oil and vitamin $E$ on the severity of periodical breast pain. Iran J Nurs Midwifery Res [Internet]. 2009 Feb 17 [cited 2018 Aug 24]; 13(3). Available from: http://ijnmr.mui.ac.ir/index. php/ijnmr/article/view/59.

\begin{tabular}{|c|c|c|c|}
\hline \multicolumn{4}{|c|}{ AUTHORSHIP AND CONTRIBUTION DECLARATION } \\
\hline Sr. \# & Author-s Full Name & Contribution to the paper & Author $=s$ Signature \\
\hline 1 & Ramlah Ghazanfor & Original Idea, Manuscript writing. & $\operatorname{lom}_{x \rightarrow 0}$ \\
\hline 2 & Usman Qureshi & Editing. & \\
\hline 3 & Rafay Ghazanfer Adil & $\begin{array}{l}\text { Data analysis, Result section } \\
\text { writing. }\end{array}$ & \\
\hline 4 & Sara Malik & Data collection. & \\
\hline 5 & Maham Tariq & Data collection. & \\
\hline 6 & Jahangir Sarwar Khan & Supervision of profect. & 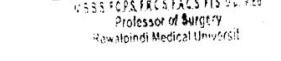 \\
\hline
\end{tabular}

